\title{
Nimistöntutkijoiden kansainvälinen yhteisö suomalaiskomennossa
}

26. nimistöntutkimuksen kansainvälinen kongressi (International Congress of Onomastic Sciences) järjestettiin Unkarin Debrecenissä 27.8.-1.9.2017. Kolmen vuoden välein järjestettävä tapahtuma on onomastiikan alan suurin. Tänä vuonna siihen osallistui noin 230 henkilöä 41:stä eri maasta ja esitelmiä pidettiin noin 210 . Kongressin teemana oli paikallisuus ja kansainvälisyys nimistössä, joskaan se ei näkynyt esitelmien sisällöissä mainittavasti.

Tapahtumapaikkana toimi Debrecenin yliopiston näyttävä päärakennus. Vanhan rakennuksen osin puutteellinen ilmastointi teki päivistä varsin raskaita, sillä lämpötilat kipusivat 25-35 asteeseen.

Suomalaisia osallistujia oli ilahduttavan paljon, kaikkiaan 14. Suomalaiset kantavat tällä hetkellä suurta vastuuta nimistöntutkijoiden kansainvälisen yhteisön toiminnasta. International Council of Onomastic Sciences -järjestön (myöh. ICOS) yleiskokouksessa presidentiksi tulevalle kolmivuotiskaudelle valittiin Paula Sjöblom Turun yliopistosta. Sjöblom on ensimmäinen suomalainen puheenjohtaja ICOSin 68-vuotisen historian aikana. Hallituksen opiskelijajäseneksi valittiin Lasse Hämäläinen Helsingin yliopistosta. UnniPäivä Leino Tampereen yliopistosta puolestaan jatkaa ICOSin tieteellisen aikakauslehden, Onoman, päätoimittajana.

\section{Kutsupuheenvuorot}

Kongressissa kuultiin kolme kutsuttua esitelmää. Tapahtuman avasi Grant W. Smithin puheenvuoro erisnimien symbolisista merkityksistä. Keskusteluun nimien merkityksistä ovat ottaneet historian saatossa osaa monet tunnetut kielifilosofit, kuten
John Stuart Mill, Charles Peirce ja Saul Kripke. Smith arvioi heidän näkemyksiään osin kriittisesti ja perusti oman näkemyksensä paitsi kielitieteiden myös psykologian ja biologian tutkimustuloksiin.

István Hoffmann ja Valéria Tóth käsittelivät paikannimien etymologian ja muuttumisen teoreettisia kysymyksiä sekä paikannimien typologisia piirteitä unkarilaisen aineiston pohjalta. He nostivat esiin kansainvälisen yhteistyön tarpeellisuuden. Heidän mukaansa kansainvälisissä projekteissa kannattaisi tutkia erityisesti vesistönimiä ja henkilönnimiin pohjautuvia asutusnimiä, sillä ne ovat hedelmällisiä tutkimuskohteita eri kielten nimistöjen vertailun kannalta.

Staffan Nyströmin aiheena olivat paikannimistön huolto ja suunnittelu etenkin Pohjoismaissa. Paikannimilailla on suuri merkitys nimistön säätelylle, säilyttämiselle ja suunnittelulle. Suomessa sitä ei ole - toisin kuin useimmissa muissa Pohjoismaissa. Nyström nosti myös esiin nimistön kaupallistumisen ja englanninkielistymisen, joka näkyy muun muassa liikunta- ja urheiluhallien nimissä (esim. Läkerol Arena, Swedbank Arena). Hän haastoi nimistöntutkijat vastustamaan tällaista kehitystä.

\section{Symposiumit}

Yksi kongressipäivä oli omistettu temaattisille symposiumeille. Niiden aiheet voitaneen tulkita järjestäjien näkemykseksi siitä, mitkä teemat ja kysymykset ovat tämänhetkisessä onomastiikassa tärkeitä.

Henkilön- ja paikannimien suhteita käsittelevässä symposiumissa arvioitiin näiden kahden nimisysteemin vaikutusta toisiinsa. Monissa esitelmissä selvitet- 
tiin numeerisesti, kuinka paljon paikannimissä on henkilönnimikantaista ainesta ja päinvastoin. Useimmiten aihetta lähestyttiin jonkin valtion kontekstissa. Suomalaisista symposiumissa esiintyivät Jaakko Raunamaa, joka puhui esikristillisten henkilönnimien esiintymisestä itämerensuomen alueen kylännimissä, sekä UnniPäivä Leino, joka loi katsauksen suomalaisiin paikan-, etu- ja sukunimiin sekä niiden keskinäisiin päällekkäisyyksiin.

Keski-Euroopan nimisysteemien keskinäisiä kontakteja käsittelevässä symposiumissa kuultiin esitelmiä niin paikan- kuin henkilönnimistöstä. Useimmat esitykset keskittyivät käsittelemään tarkemmin rajattua maantieteellistä aluetta (Puola, Transilvania, Tšekki, Viro), mutta Peter Jordanin ja Christian Zschieschangin esitelmien esimerkit olivat useilta eri alueilta. Joissakin esitelmissä myös määriteltiin ja problematisoitiin KeskiEuroopan käsitettä.

Viime aikoina kenties vahvimmin kasvanut nimistöntutkimuksen osa-alue on sosio-onomastiikka. Sen rajat ja kysymyksenasettelut ovat kuitenkin vielä osin muotoutumassa. Terhi Ainialan ja Erzsébet Győrffyn järjestämän symposiumin aiheena olivatkin sosio-onomastiikan nykytila ja tehtävät. Esitelmiä kuultiin muun muassa nimikompetenssista (Erzsébet Győrffy, Magdolna Nemes), lempinimistä (Linnea Gustafsson), verkon henkilönnimistöstä (Lidia Becker) ja nimimaisemasta (Väinö Syrjälä).

Nimistöntutkijoiden kansainvälistä yhteistyötä käsitelleen symposiumin avasi Tamás Farkasin yleiskatsaus erilaisiin alan tutkijajärjestöihin. Tämän jälkeen useat niistä, muun muassa suomalaisille tuttu Nordiska samarbetskommittén för namnforskning eli NORNA, esittäytyivät. Symposiumissa esiteltiin myös onomastisia yhteistyöprojekteja, joiden tuloksena syntyy etenkin uusia tutkimusaineistoja. Suurin osa projekteista on yliopistojen tai tutkimuslaitosten järjestämiä, mutta niitä on myös yliopistojen ja laitosten ulkopuolella.

Soveltavan nimistöntutkimuksen symposiumissa kuultiin esitelmiä hyvin monenlaisista aiheista. Judit Kecskés kertoi projektista, jossa maahanmuuttajaoppilaita integroidaan unkarilaiseen peruskouluun muun muassa nimistön avulla. Terhi Ainiala ja Johanna Lehtonen puolestaan esittelivät kahta nimistöntutkimuksen kurssia, joilla yliopistoopiskelijat osallistuivat Helsingin kaupungin nimistönsuunnitteluun. Symposiumissa järjestettiin myös kolme paneelikeskustelua, joista yksi käsitteli nimiä ja markkinointia, toinen nimiä, globalisaatiota ja opetusta ja kolmas soveltavan onomastiikan tutkimuskohteita, tehtäviä ja foorumeita.

\section{Paikannimitutkimus muutoksessa}

Selvästi laajin nimistöntutkimuksen osaalue on yhä paikannimistön tutkimus. On kuitenkin havaittavissa, että yhteiskunnalliset ja teknologiset muutokset muuttavat sen painopisteitä. Perinteisintä tutkimusta on ollut nimien etymologioiden selvittely, mutta nyt tällaisia esityksiä oli vähän. Sen sijaan näyttää käyvän yhä yleisemmäksi, että paikannimitutkimus kytkeytyy yhteen muiden tieteenalojen intressien kanssa.

Perinteisiä yhteistyökumppaneita ovat historiatieteet ja erityisesti kielihistoria. Esimerkkejä tällaisista asetelmista ovat Carole Houghin tutkimus paikannimien roolista muinaisenglannin aikaisten murteiden selvittelyssä ja Csilla Katonan tutkimus vanhojen paikannimien käytöstä historiallisten äänteenmuutosten tarkastelussa. Paikannimet ovat hedelmällistä aineistoa myös kielikontaktien tutkimuksessa. Kongressissa kuultiinkin runsaasti kontaktionomastiikkaa edustavia esitelmiä.

Uudet teknologiat voivat helpottaa paikannimitutkimusta ja näin muuttaa 
tutkimustyön luonnetta. Esimerkiksi Alexandra Petrulevichin ja Agnieszka Backmanin esittelemässä projektissa The Norse perception of the world sijoitetaan vanhoissa lähteissä esiintyviä paikannimiä kartalle GIS-pohjaisen karttateknologian avulla. Näin on esimerkiksi helppo havaita, mitä erilaisia Suomeen liittyviä nimiä viikinkiajan maailmassa on käytetty.

Paikannimet voivat olla osa politiikkaa. Jaroslav David pohti, tulisiko sosialistista ideologiaa edustavia paikannimiä muuttaa entisen Tšekkoslovakian alueen kaupungeissa. David itse on sosialistisen nimistön säilyttämisen kannalla, koska se on osa paikallista kulttuuriperintöä, vaikka edustaakin synkkää jaksoa historiassa. Unkarilainen Réka Imreh puolestaan esitteli tuoreen esimerkin siitä, miten nimistö on valjastettu palvelemaan kansallisuusaatetta. Nationalismi on viime vuosina voimistunut Unkarissa, ja ideologisista syistä jopa unkarin suomalais-ugrilaista alkuperää on alettu kyseenalaistaa tiedeyhteisön ulkopuolella. Niin paikannimille kuin etunimille on sepitetty uusia epätieteellisiä, kansallismieliseen ideologiaan sopivia etymologioita.

Paikannimien osaamisen eli nimikompetenssin tutkimuksella näyttää olevan vahva asema etenkin Unkarissa, sillä kolme unkarilaista esitelmöi aihetta käsittelevien tutkimustensa pohjalta. Alan suomalaisia perinteitä jatkaa Anni MaggaEira, joka esitteli tutkimustaan saamelaisten poronhoitajien nimikompetenssista. On kuitenkin syytä huomata, että näissä esitelmissä, kuten nimikompetenssitutkimuksissa yleensäkin, tarkasteltiin vain paikannimien osaamista. Nähdäksemme olisi mielenkiintoista ja tärkeää saada vastaavanlaisia tutkimustuloksia myös muiden nimikategorioiden osalta.

\section{Henkilönnimet ennen ja nyt}

Paikannimien ohella tähänastinen nimistöntutkimus on painottunut henkilön- nimiin. Henkilönnimistön yleispiirteitä on jo kuvattu varsin perusteellisesti monissa maissa, muttei läheskään kaikkialla. Esimerkiksi Osward Penda esitteli Sambian henkilönnimien typologiaa, Alexander Pustyakov taas marilaisten nimitraditioita.

Kongressissa kuultiin runsaasti historiallista henkilönnimistöä käsitteleviä esitelmiä. Erityisesti Keski-Euroopassa tällainen tutkimus on suosittua, mikä ei ole yllätys ottaen huomioon aineiston runsauden, joka alueen tutkijoilla on käytössään. Toisaalta esityksiä kuultiin myös lyhyemmän aikaa kirjallisen kulttuurin piirissä olleilta alueilta. Evar Saar kertoi Kaakkois-Viron 170o- ja 180o-lukujen slaavilaisperäisistä henkilönnimistä ja Jaakko Raunamaa keskiajan Suomessa käytetyistä naistennimistä.

Myös uusia näkökulmia henkilönnimien tarkasteluun nousi esiin. Johanna Virkkula pohti sitä, missä määrin nimien pitää olla samanlaisia, jotta niitä voi pitää samoina niminä. Ovatko esimerkiksi nimien Luca ja Luka tai Daniel ja Daniela kantajat kaimoja? Maria Sarhemaa puolestaan esitelmöi etunimien appellatiivistumisesta suomessa ja unkarissa sekä This Michel Fetzer sveitsinsaksassa.

Yksi henkilönnimiasiantuntijoita koskettava aihe ovat nimenantoa säätelevät lait. Suomessa on juuri tehty esitys nimilain uudistamiseksi. Tästä näkökulmasta erityisen kiinnostava oli Katharina Leibringin katsaus Ruotsissa tehtyyn, 1.7.2017 voimaan tulleeseen, lakiuudistukseen. Sen myötä kuka tahansa voi ottaa minkä tahansa sellaisen sukunimen, jolla on yli 2 ooo kantajaa. Zoltán Pálffi-Megyeri taas tarkasteli Unkarin nimilain historiaa selvittämällä, millaisia nimivaihtoehtoja unkarilaisnaisella on ollut avioituessaan eri aikakausina.

\section{Muu nimistöntutkimus}

Vaikka paikan- ja henkilönnimien tutkimus hallitsee yhä onomastiikan alaa, 
tutkimusaiheiden kirjo laajenee hiljalleen. Jokseenkin uusia aluevaltauksia ovat muun muassa grillikioskien ja -ruokien nimet (Terhi Ainiala), vapaamuurarien salanimet (Zsuzsanna Berényi), jalkapallomaajoukkueiden lempinimet (Nobuhle Hlongwa) ja videopelien radannimet (Lasse Hämäläinen).

Kirjallisuuden nimistö on nostettu yhdeksi onomastiikan pääluokista hiljattain ilmestyneessä nimistöntutkimuksen uudessa käsikirjateoksessa (Hough 2016; ks. myös Hämäläinen, Raunamaa \& Syrjälä 2017: 304). Kongressissa se ei kuitenkaan ollut erityisen näkyvästi esillä. Useimmat aihetta koskeneet esitelmät olivat tapaustutkimuksia, katsauksia nimistöön tietyssä kirjassa tai tietyn kirjailijan tuotannossa.

Sosio-onomastiikka puolestaan esiintyi ohjelmassa taajaan. Symposiumin lisäksi muina kongressipäivinä järjestettiin useita sille omistettuja sektioita. Tässä lienee kyse paitsi alan kasvusta myös siitä, että sen rajat ovat vielä osin epäselvät. Sosio-onomastiikan alle on viime vuosina kerääntynyt sellaisia aiheita, jotka aiemmin olisi sijoitettu muihin kategorioihin. On kuitenkin syytä muistaa, että esimerkiksi kaupalliseen nimistöön tai verkon käyttäjänimiin kohdistuva tutkimus ei ole automaattisesti sosioonomastista (vrt. Hough 2016: 438-464).

Other names -otsikoituihin sektioihin oli sijoitettu myös useita esitelmiä, joiden aiheet voisi lukea osaksi paikannimitutkimusta. Tällaisia olivat muun muassa esitykset japanilaisten pikajunatunnelien nimistä (Toyomi Nakaba), singaporelaisten rakennusten nimistä (Peter Tan) sekä lentokenttien muistonimistä eri maissa (Sami Suviranta).

\section{Kulttuurieroja}

Vaikka nimistöntutkimus on nykyään kansainvälisempää kuin koskaan ennen, on eri maiden välillä yhä selviä eroja. Monissa maissa nimistöntutkimus on yhä valtaosin paikannimitutkimusta. Suomessa ja useissa muissa läntisen Euroopan maissa tutkimusaiheiden kirjo on kuitenkin monipuolistunut viime aikoina huomattavasti.

Kulttuurierot tulivat esille myös suullisen esiintymisen käytännöissä. Osa tutkijoista kirjoittaa esitelmät valmiiksi ja lukee ne paperista varsin formaalilla tieteellisellä kielellä. Osa taas puhuu vapaamuotoisemmin, käyttää selvästi tieteellistä artikkelitekstiä yksinkertaisempaa ilmaisua ja havainnollistaa esitystä Powerpointin avulla. Nähdäksemme jälkimmäinen käytäntö sopii nykyiseen tieteelliseen kulttuuriin paremmin.

Seuraava nimistöntutkimuksen kansainvälinen kongressi järjestetään elokuussa 2020 Puolan Krakovassa.

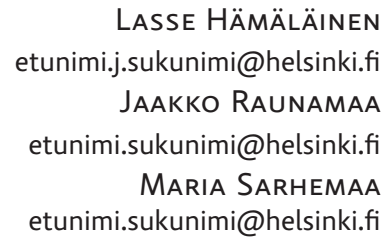

LASSE HÄMÄLÄINEN etunimi.j.sukunimi@helsinki.fi JAAKKO RAUNAMAA etunimi.sukunimi@helsinki.fi Maria SARHEMAa etunimi.sukunimi@helsinki.fi

\section{Lähteet}

Hough, CArole (toim.) 2016: Oxford handbook of names and naming. Oxford: Oxford University Press.

\footnotetext{
HÄMÄLÄINEN, LASSE - RAUNAMAA,

JAAKKO - SYRJ̈̈LÄ, VÄINÖ 2017: Nimistöntutkijan uusi käsikirja.

- Virittäjä 121 s. 301-308.
} 